\title{
Aggregation, Community, and the Line Between
}

\author{
Elizabeth Chamblee Burch ${ }^{*}$
}

\section{INTRODUCTION}

As class action theorists, we tend to think heavily about when and whether to certify a class-whether attorneys are seeking principally equitable relief for a Rule 23(b)(2) class, what the limits of a fund should be before certifying a Rule 23(b)(1)(B) class, and generally whether a group is cohesive enough for certification. Sometimes we focus so much on determining when plaintiffs have met the certification threshold that we neglect to reassess the line itself. To some, class action line drawing is an ontological question. If a group meets certain certification criteria, then Rule 23 transforms the individual claims of those within it into "entity claims," making the client the entity itself. ${ }^{1}$ Consequently, some scholars suggest that a certified class may have an ontological status apart from the aggregate of its individual members. ${ }^{2}$ Others find this preposterous. ${ }^{3}$ Of course, the theories differ slightly depending on the type of class. But all theories employ roughly the same yardstick: do the procedurally aggregated individuals form a sufficiently cohesive group before the decision to sue? ${ }^{4}$

Given this symposium's topic - the state of aggregate litigation and the boundaries of class actions in the decade after Amchem Products, Inc.

\footnotetext{
* Assistant Professor, Florida State University College of Law. I am indebted to Curtis Bridgeman, Thomas Burch, Brannon Denning, and Alexandra Lahav for their comments on previous drafts, to symposium participants for their thought-provoking questions, and to Laura Hines and the Kansas Law Review for organizing this symposium.

1. David L. Shapiro, Class Actions: The Class as Party and Client, 73 Notre Dame L. REV. 913, 919 (1998).

2. See, e.g., id. at 918-19 (noting that "the entity is the litigant and the client"); see also Edward H. Cooper, Rule 23: Challenges to the Rulemaking Process, 71 N.Y.U. L. REV. 13, 26-27 (1996); cf. Samuel Issacharoff, Preclusion, Due Process, and the Right to Opt Out of Class Actions, 77 Notre DAME L. REV. 1057, 1060 (2002) ("[T]here is increasing skepticism over the view that a class action is simply an unaltered aggregation of individual claims.").

3. See, e.g., Martin H. Redish \& Nathan D. Larsen, Class Actions, Litigant Autonomy, and the Foundations of Procedural Due Process, 95 CAL. L. REV. 1573, 1590-97 (2007).

4. This is occasionally assessed at the time the plaintiffs move for class certification, if, for instance, they have narrowed their proposed class definition.
} 
v. Windsor ${ }^{5}$ and Ortiz v. Fibreboard Corp. ${ }^{6}$ - the time is ripe to challenge our assumptions about this yardstick. Accordingly, this Article examines group cohesion and asks whether the current line is the only dividing line or even the correct one. Although I rely on class action analogies, I am particularly concerned about mass-tort litigation that proceeds as nonclass litigation because it fails Rule 23(b)(3)'s predominance test.

A closer look at the aims of our current line reveals that it depends on common traits among class members to justify interest representation. This, of course, is not a new revelation, nor is it particularly surprising that scratching beneath the veneer of commonality often reveals a bevy of conflict. Yet, historically, class action treatment traced actual group cohesion, which suggests an alternative means for binding present litigants in nonclass aggregation if we are less concerned about freezing interests in their pristine pre-litigation form. If the judicial system encourages procedurally aggregated plaintiffs to communicate with one another about their litigation aims, injuries, and intentions, then they may form genuinely cohesive groups. Accordingly, if courts look beyond the proxies used to evaluate pre-litigation unity to actual cohesion after the decision to sue, then they should permit like-minded plaintiffs to bind their collective interests.

Part II considers some of the ironies in the current line-drawing scheme to make the case for a different line in nonclass aggregation. In particular, Part II questions the authenticity of the "presumption of cohesion" that attaches to Rule 23(b)(2) class actions and whether the proxies used to test cohesion in Rule 23(b)(3) classes are realistic gauges of homogeneity. Because group litigation evolved historically from actual, interconnected group rights, the modern iteration of Rule 23 tacks the moniker "cohesion" onto procedurally aggregated individuals with superficial similarities. This leads some scholars to claim that the class action subverts individual autonomy and threatens fundamental aspects of a liberal democracy. ${ }^{7}$

Still, my aim is not to attack the current line as it relates to class actions. Rather, it is to say that if we are willing to look for genuine cohesion among individuals who are procedurally aggregated but lack sufficiently common traits before the decision to sue, then we will find an alternative and perhaps more compelling justification for binding collective interests. Part III thus explains how genuine cohesion and

5. 521 U.S. 591 (1997).

6. 527 U.S. 815 (1999).

7. See infra Part II.B. 
community among plaintiffs might occur. While our basic definitions of community remain the same, modern communication methods have made it possible to develop and maintain affective ties with people outside of our immediate geographic location. These new media allow plaintiffs without previous affiliations to create and sustain a sense of community based on their shared histories, experiences, and attributes.

Finally, Part IV draws on the dominant justifications for group litigation - consent and interest representation-to explore this alternative line-drawing scheme in terms of political theory. Encouraging plaintiffs to form groups and reach decisions through deliberation relies on a mix of individual consent and moral obligation. Allowing plaintiffs to exercise their free will when deciding whether to associate with others preserves the liberal tenet of self-determination and escapes the anti-democratic criticism leveled at class actions. Yet, a purely liberal approach fails to capture the obligatory aspect of reciprocal promises to cooperate and the communal obligations that attach. Although plaintiffs voluntarily enter into the group, once they are group members and have tied together their collective litigation fates, they should not be permitted to exit when doing so violates their commitments. Of course, the community itself determines the content of its members' rights and obligations to one another. Thus, this section concludes by explaining the rationale for group autonomy in terms of pluralism and communitarianism.

\section{THE PARTY LINE}

The current line-drawing regime for class actions uses a snapshot approach: courts determine whether a homogeneous group of people with shared traits existed or shared those attributes before the litigation. The idea is to adjudicate rights in their pre-litigation form. In this picture, rights and obligations are frozen in time; the "groupness" of a set of individuals is static. Consider, for example, how judges determine whether to certify Rule 23(b)(2) and 23(b)(3) claims.

First, consider Rule 23(b)(2), where "the party opposing the class has acted or refused to act on grounds that apply generally to the class, so that final injunctive relief or corresponding declaratory relief is appropriate respecting the class as a whole." ${ }^{\circ}$ Typical (b)(2) classes include employment-discrimination claims, where the employer fails to hire or promote people of a certain race or gender, or civil-rights

8. FED. R. CIV. P. 23(b)(2). 
violations, such as the school-desegregation cases. ${ }^{9}$ Because (b)(2) classes remedy group injuries through uniform relief, courts look for a clear group trait like race or gender and presume that class members are cohesive and homogeneous so long as that unifying trait existed before the litigation. ${ }^{10}$ Because (b)(2) class actions do not require opt-out opportunities, ${ }^{11}$ assuming cohesion allays judges' qualms about dueprocess concerns such as personal notice and the ability to exit. A court daring to recognize potentially divergent interests would be hard-pressed not to provide notice and opt-out rights. ${ }^{12}$ Consequently, presuming that class members' interests are cohesive, even when that presumption is fictitious, prevents the instabilities and opt-outs that jeopardize the collective good in Rule 23(b)(3) class actions.

Presuming pre-litigation cohesion is frequently just a convenient assumption. Take, for instance, employment class actions where the group is ready-made: a certain category of employees work for a given employer. As anyone who has been around a university department surely knows, professors may disagree over everything from curricular reform to which speakers to invite. It is not surprising, then, that in any given employment class action there will be diverse preferences. Some faithful employees will eschew the decision to sue at all, others will worry about retaliation, others may be risk adverse, and still others may want different relief. ${ }^{13}$

Some courts are willing to look behind the imperial curtain and allow parties to rebut the "presumption of cohesion."14 For instance, Judge

9. See id. advisory committee's note to 1966 Amendment.

10. See, e.g., Robinson v. Metro-North Commuter R.R., 267 F.3d 147, 165 (2d Cir. 2001) (noting a "presumption of cohesion and unity between absent class members and the class representatives" when "class-wide injunctive or declaratory relief is sought"); Allison v. Citgo Petroleum Corp., 151 F.3d 402, 402 (5th Cir. 1998) (race); Holmes v. Cont'l Can Co., 706 F.2d 1144, 1155 n.8 (11th Cir. 1983) (race and gender); Wetzel v. Liberty Mut. Ins. Co., 508 F.2d 239, 248-49 (3d Cir. 1975) (gender); Roe v. Bridgestone Corp., 257 F.R.D. 159, 170-72 (S.D. Ind. 2009) (finding age insufficient for a child-labor claim under the Alien Tort Statute); In re Methyl Tertiary Butyl Ether Prod. Liab. Litig. (MTBE Litig.), 209 F.R.D. 323, 343 (S.D.N.Y. 2002) ("Class members in a (b)(2) action must share some "preexisting legal relationship or [a] significant common trait such as race or gender." (quoting Holmes, 706 F.2d at 1155)).

11. See FED. R. Civ. P. 23(c)(2)-(3).

12. See Lemon v. Int'l Union of Operating Eng'rs, Local 139, 216 F.3d 577, 580 (7th Cir. 2000).

13. Similar problems arose in the 1970s school-busing cases; many parents would have preferred to avoid busing, violence, and poor (but integrated) schools. See generally Derrick A. Bell Jr., Serving Two Masters: Integration Ideals and Client Interests in School Desegregation Litigation, 85 YALE L.J. 470 (1976).

14. Courts occasionally allow Rule 23(b)(2) classes to progress as such on the liability phase, but then permit notice and opt-out rights if class cohesion fails during the remedial stage. See, e.g., Robinson, 267 F.3d at 166-67; Latino Officers Ass'n v. City of New York, 209 F.R.D. 79, 93 
Scheindlin allowed defendants to rebut homogeneity by demonstrating that individual issues existed in the MTBE litigation. ${ }^{15}$ But other courts hold tightly to this presumption even in the face of heterogeneity. ${ }^{16}$ The point is, even in (b)(2) classes, plaintiffs' opinions about risk, relief, and strategy may differ vastly even though plaintiffs share a similar trait before suing. ${ }^{17}$ Consequently, this assumption often camouflages what is truly only an amalgamation of people's divergent interests.

By contrast, in Rule 23(b)(3) class actions, the predominance test asks "whether proposed classes are sufficiently cohesive to warrant adjudication by representation." 18 Cohesion legitimizes collective representation. But this is not necessarily group cohesion. Courts typically use common characteristics - such as the same physical injuries, product, disaster, circumstances, or state laws - as proxies for class cohesion and homogeneity. ${ }^{19}$ The commonalities binding the proposed class must then predominate over individual interests. One unusual example to the contrary is in appointing a lead plaintiff in Rule 23(b)(3) securities class actions. There, courts have been willing to designate a group as the lead plaintiff if its members have either a prelitigation or a post litigation relationship so long as they are cohesive, function together smoothly, and monitor the lawyers. ${ }^{20}$ To evaluate cohesiveness, courts do consider whether group members have a prelitigation relationship, but they also examine the members' litigation involvement, plans to cooperate, sophistication level, and whether they chose counsel or vice versa. ${ }^{21}$

(S.D.N.Y. 2002).

15. MTBE Litig., 209 F.R.D. at 343.

16. See, e.g., Waters v. Barry, 711 F. Supp. 1125, 1130-32 (D.D.C. 1989). Before this presumption emerged, some courts observed that unanimity was impossible and not a class action prerequisite. See, e.g., Horton v. Goose Creek Indep. Sch. Dist., 690 F.2d 470, 485-86 (5th Cir. 1982); Wyatt ex rel. Rawlins v. Poundstone, 169 F.R.D. 155, 161 (M.D. Ala. 1995).

17. See Deborah L. Rhode, Class Conflicts in Class Actions, 34 Stan. L. Rev. 1183, 1183-84 (1982).

18. Amchem Prods., Inc. v. Windsor, 521 U.S. 591, 623 (1997).

19. See id. at 624 .

20. See, e.g., Freudenberg v. E*Trade Fin. Corp., Nos. 07 Civ. 8538, 07 Civ. 8808, 07 Civ. 9651, 07 Civ. 10400, 07 Civ. 10540, 2008 WL 2876373, at*4-5 (S.D.N.Y. July 16, 2008); In re Flight Safety Tech., Inc. Sec. Litig., 231 F.R.D. 124, 129 (D. Conn. 2005); Xianglin Shi v. Sina Corp., Nos. 05 Civ. 2154 (NRB), 05 Civ. 2268 (NRB), 05 Civ. 2374 (NRB), 05 Civ. 2391 (NRB), 05 Civ. 2503 (NRB), 05 Civ. 2826 (NRB), 2005 WL 1561438, at *5 (S.D.N.Y. July 1, 2005); Local 144 Nursing Home Pension Fund v. Honeywell Int'l, Inc., No. 00-3605 (DRD), 2000 WL 33173017, at *3-4 (D.N.J. Nov. 16, 2000); In re Oxford Health Plans, Inc. Sec. Litig., 182 F.R.D. 42,46 (S.D.N.Y. 1998)

21. Varghese v. China Shenghuo Pharm. Holdings, Inc., 589 F. Supp. 2d 388, 392 (S.D.N.Y. 2008) 
Rule 23(b)(3)'s counter-assumption to (b)(2) is, in part, economically driven. A request for money jeopardizes cohesion. ${ }^{22}$ Courts assume that people pursuing monetary claims are a less cohesive bunch both because monetary remedies are tied to individual merits and divergent interests, and because the more one has to lose, the less she may trust others with her claim. ${ }^{23}$ To be sure, part of the courts' concern in (b)(3) classes is about due process - monetary claims carry with them property rights that injunctive and declaratory relief lack. But the idea that monetary remedies are inherently divisive, whereas injunctive or declaratory relief is not, is at odds with reality. A generous explanation for the difference might be the need for due process and its corresponding right to opt out; yet, courts go further than that. They imply that when money is at stake, we will all behave as homo economicus and maximize our own outcome at the rest of the participants' expense. ${ }^{24}$ That is, we will elevate our own self-interest over that of the other plaintiffs and thereby act discordantly.

The point thus far has been that courts use several proxies to gauge pre-litigation homogeneity and unity among class members: in Rule 23(b)(2) class actions the proxy is uniform relief, and in Rule 23(b)(3) class actions the proxy is preexisting common characteristics such as physical injuries and shared circumstances. A closer look at the class action's history reveals that these proxies evolved historically from actual, interconnected group rights.

\section{A. The Historical Line}

In medieval times, life revolved around one's group memberships; the individual's rights and privileges stemmed not from her autonomy but from her membership in a particular group. Parishes, villages, guilds, boroughs, and frankpledge tithings were social and economic organizations as well as groups with collective obligations and rights. ${ }^{25}$

\footnotetext{
22. Lemon v. Int'l Union of Operating Eng'r, Local No. 139, 216 F.3d 577, 580 (7th Cir. 2000).

23. See Barabin v. Aramark Corp., No. 02-8057, 2003 WL 355417, at *2 (3d Cir. Jan. 24, 2003) (individual merits); Allison v. Citgo Petroleum Corp., 151 F.3d 402, 412-13 (5th Cir. 1998) (individual merits); Ammons v. La-Z-Boy, Inc., No. 1:04-CV-67 TC, 2008 WL 5142186, at *19 (D. Utah Dec. 5, 2008) (decreased trust); Clark v. State Farm Mut. Auto. Ins. Co., 245 F.R.D. 478, 486 (D. Colo. 2007) (decreased trust). It is equally plausible that a plaintiff would be more likely to trust others when more money is at stake, particularly if they are experts and she is not.

24. See Barabin, 2003 WL 355417 , at *1; Allison, 151 F.3d at 412-13.

25. Stephen C. Yeazell, From Medieval Group Litigation to the Modern Class ACTION 41-49 (1987). Yeazell explains that a "frankpledge" was essentially a policing institution in which young males formed groups that were responsible for one another's good behavior. Id. at 43-
} 
Communal obligations and collective power were coterminous. These joint obligations ran so deep that collectors could enforce debts from one member by demanding payment from another, simply because of her membership in the same community. ${ }^{26}$ Members of rural communitiessuch as villages, frankpledge tithings, and parishes - did not choose to become group members in any meaningful, voluntary sense; rather, membership arose from geographic location. ${ }^{27}$ Townsfolk, grouped in exclusive guilds and boroughs, on the other hand, voluntarily chose group membership by accepting responsibility and financial obligations. ${ }^{28}$ Whether chosen or not, group membership and its collective rights and obligations was a way of life that largely went unquestioned.

After the medieval period, plagues, famine, and the Reformation led to more modern bureaucratization and consolidated power in boroughs with taxes and corporations. ${ }^{29}$ Social groups were no longer coterminous with political ones. As group litigation became an anomaly rather than the norm, the nineteenth-century public felt the need to explain it in terms of consent and representation. ${ }^{30}$ As Stephen Yeazell describes it, in the mid-1800s, the political thought of Frederic Calvert concerning interest representation and Edmund Burke's notions about virtual representation reinvigorated group litigation. ${ }^{31}$

It is here that we begin to see an interweaving of political theory and procedural thought. Grappling with the ideological tensions that persist today, Calvert explained group litigation as interest representation and assumed that one person could represent others with similar interests. ${ }^{32}$ Dividing "interest" into two meanings, he thought the word could mean either an interest in the property or transaction, or an interest in the question the litigation presents. ${ }^{33}$ Put differently, one might be interested in the object of the lawsuit or in the suit's subject matter. This latter interest paved the way for associations-such as homeowners'

44.

26. Id. at $61-63$.

27. Id. at $41-52$.

28. Id. at $58-68$

29. Id. at $100-08,123-25$.

30. Id. at 178 .

31. Id. at $198-210$

32. Robert G. Bone, Personal and Impersonal Litigative Forms: Reconceiving the History of Adjudicative Representation, 70 B.U. L. REV. 213, 224 (1990) (reviewing YEAZELL, supra note 25).

33. Frederic Calvert, A Treatise Upon the LAW Respecting Parties to SuIts IN EQUITY 5-7 (London, Saunders and Benning 1837). 
associations, unions, and lodges - to sue on their members' behalf and purportedly protect their collective interest. ${ }^{34}$

Meanwhile, a few years earlier, Edmund Burke promoted a political version of interest representation and contended that there was no need for a geographic locale to have its own representative so long as another representative elsewhere shared that locale's interests. ${ }^{35}$ From this came the idea of virtual representation where a nonparty is situated such that "one of the parties to the suit is so closely aligned with his interests as to be his virtual representative." 36 In both political and procedural theory then, this notion further distanced representation from consent and tied it instead to interests.

From this brief historical summary, three key points emerge. First, our current line-drawing regime, which uses proxies for determining whether group homogeneity existed before the litigation, is rooted in (1) what used to be an actual community and (2) interest representation. Thus, in one sense, these proxies have become convenient fictions for assuming group cohesion, much like the renewed judgment as a matter of law is a convenient turn of phrase to circumvent the Seventh Amendment's reexamination clause. ${ }^{37}$ The historical predicates to these proxies turned on a mix of consent - through voluntarily joining social organizations in medieval times or, according to Calvert, joining a lawsuit affecting one's interests - and purely similar interests. Second, it becomes apparent that our now near-divorced conceptions of law and sociality used to be quite closely linked. Rather than thinking about procedural law or social norms, both are integral to a holistic understanding of either. Our inherent sociality and ideology matter immensely to our understanding of group cohesion, group representation, and procedural aggregation. Third, scratching beneath the surface of the modern-day presumptions of class cohesion commonly reveals heterogeneity, not homogeneity. Accordingly, in a society founded on individual rights, we continue to struggle with notions of consent and interest representation to justify binding collective interests.

34. Samuel Issacharoff, Governance and Legitimacy in the Law of Class Actions, 1999 SuP. CT. REv. 337, 364 (1999).

35. YEAZELL, supra note 25, at 205-06.

36. Aerojet-General Corp. v. Askew, 511 F.2d 710, 719 (5th Cir. 1975). Taylor v. Sturgell contains the Supreme Court's most recent word on virtual representation. 128 S. Ct. 2161, 2178 (2008) (disapproving a theory of preclusion by virtual representation). Intervention in Rule 24 relies on much the same concept.

37. See FED. R. CIV. P. 50(b) (allowing renewed motion for judgment as a matter of law). 


\section{B. Democratic Drawbacks of the Current Line}

In its modern form, the class action has been attacked from all sides for many reasons. Of particular interest here, however, is the criticism that current class action litigation is undemocratic. As Martin Redish contends, the class action reworks substantive laws and thereby circumvents the democratic process by undermining accountability and representation. ${ }^{38} \mathrm{He}$ sees today's class action as essentially a shell game, a purportedly procedural device that does not actually compensate and operates instead as a tool for rogue bounty hunters who act without the legitimacy of substantive authorization. ${ }^{39}$ Reading the class action's historical development, he contends:

On the one hand, while early English practice did authorize certain forms of purely collective adjudication, it appears that in none of those contexts were individuals forced to adjudicate substantive rights that, in their pristine pre-litigation form, were individually held. Rather, collective adjudication was permitted only when the individual's substantive rights were held as part of a pre-existing entity. ${ }^{40}$

Underlying this critique is the further argument that forcing collective adjudication of individually held rights subverts individual autonomy, a concept so important to modern American thought that it runs throughout both our judicial and political system. Here, Redish contends that "the modern class action also threatens core notions of liberal democracy on a micro level, by restricting the individual's autonomous ability to employ the judicial process as a means of protecting her substantive legal rights." ${ }^{41}$ In this manner, class actions undermine individual liberal values such as integrity, autonomy, and self-worth.

In sum, our current pre-litigation line-drawing scheme: (1) presupposes unity where none exists; (2) relies on proxies such as skin color, gender, common injuries, similar circumstances, and comparable state laws to determine whether individuals, who may be nothing more than procedurally aggregated, constitute a "group"; (3) employs representative notions based on the fiction these proxies create and thereby undermines individual autonomy and integrity; and (4) raises

38. Martin H. Redish, Wholesale Justice 21-61 (2009); Martin H. Redish, Class Actions and the Democratic Difficulty: Rethinking the Intersection of Private Litigation and Public Goals, 2003 U. CHI. LEGAL F. 71, 81-82.

39. Redish, supra note 38 .

40. REDISH, supra note 38 , at 230 .

41. Id. at 229 . 
democratic concerns about accountability and representation. On the positive side, this line provides a fixed point in time for assessing Rule 23 's requirements and thereby avoids the ambiguity of assessing cohesion for a moving target. Rule 23(b)(2)'s presumption of cohesion is pragmatic, if not realistic. Without the presumption, divergent interests could ruin the efficiency and momentum gained by collectivity as well as make uniform relief difficult to fashion. Proxies such as skin color, gender, and common circumstances are easier for both lawyers and judges to assess on the fly; they need not dig too deeply to determine cohesion. Finally, because class actions by definition involve absent class members, the current line avoids the stickiness of attempting to involve thousands of potentially disinterested people in the litigation and thereby undermining the class's efficiency gains.

This pre-litigation line also means that courts certify fewer putative (b)(3) class actions, particularly products-liability or personal-injury claims. The combination of Amchem, Ortiz, the Class Action Fairness Act, and the trend toward requiring plaintiffs to establish Rule 23's certification criteria by a preponderance of the evidence has substantially decreased the likelihood that a judge will certify a mass-tort class action. ${ }^{42}$ Yet, this does not mean that these actions will not proceed en masse. One need look only to the recent Zyprexa or Vioxx litigation for evidence of thousands of parties litigating nominally related claims in the same forum. ${ }^{43}$ But, because these claims are not certified as class actions, they proceed in a procedural no man's land-somewhere in between individual litigation and class action litigation, but without the protections of either. ${ }^{44}$

42. Class Action Fairness Act of 2005, Pub. L. No. 109-2, 119 Stat. 4 (2005) (codified in scattered sections of 28 U.S.C.); Ortiz v. Fibreboard Corp., 527 U.S. 815 (1999); Amchem Prods., Inc. v. Windsor, 521 U.S. 591 (1997). The following cases illustrate the preponderance of the evidence standard as well as a corresponding willingness to look into the merits of the case at class certification. See In re Hydrogen Peroxide Antitrust Litig., 552 F.3d 305, 311-12 (3d Cir. 2008) ("[T]he task for plaintiffs at class certification is to demonstrate that the element of antitrust impact is capable of proof at trial ...."); Oscar Private Equity Invs. v. Allegiance Telecom, Inc., 487 F.3d 261, 268 (5th Cir. 2007) ("Rule 23's requirements must be given their full weight independent of the merits."); In re IPO Sec. Litig., 471 F.3d 24, 40 (2d Cir. 2006) ("This standard of review implies that a district judge has some leeway as to Rule 23 requirements ...."); Szabo v. Bridgeport Machs., Inc., 249 F.3d 672, 676 (7th Cir. 2001) ("[I]f some of the considerations under Rule 23(b)(3) ... overlap the merits ... then the judge must make a preliminary inquiry into the merits.")

43. In re Vioxx Prod. Liab. Litig., 574 F. Supp. 2d 606, 611-12 (E.D. La. 2008); In re Zyprexa Prod. Liab. Litig., 433 F. Supp. 2d 268, 271 (E.D.N.Y. 2006); see also Howard M. Erichson, Informal Aggregation: Procedural and Ethical Implications of Coordination Among Counsel in Related Lawsuits, 50 DUKE L.J. 381, 386-401 (2000) (discussing plaintiffs' coordination).

44. Elizabeth Chamblee Burch, Litigating Together: Social, Moral, and Legal Obligations 8 (Feb. 28, 2009) (unpublished manuscript, on file with author). 
As I have explored elsewhere, this no man's land fosters: (1) agency problems between the attorney and her clients (misallocation incentives, inadequate attorney-client communication, and an inability for clients to monitor their case); (2) group problems between nominally related plaintiffs (incentives to holdout in settlements requiring near unanimity, outliers who want no part of group membership, and subgroup competition); and (3) competition problems between plaintiffs' attorneys. ${ }^{45}$ Accordingly, the remainder of this Article focuses on nonclass aggregation and imagines that drawing another line might overcome some of the concerns with the current class action scheme. Just as courts have allowed cohesive groups to serve as lead plaintiffs in securities class actions, this new line is based on actual group cohesion, regardless of whether that cohesion predates or postdates the decision to sue. It would also enable present plaintiffs with similar litigation ends and injuries to consciously join forces and bind their interests. After all, the current line already joins litigants based on the fiction of cohesion. Imagine then the very real justification for binding individual claims when that cohesion is genuine and litigants actually form a group based on shared interests, desires, or ends.

\section{Post AgGRegation COMMUNity}

While the class action line, which requires some approximation of a preexisting group, has remained relatively stationary since its initial 1966 iteration, our notion of community is fluid. With economic independence and the autonomy that comes with it, our ideas about community and social networks have evolved. While most of us would balk at having to pay our neighbor's debts, as individuals did in medieval times, we are seeing a resurgence of community in both old and new outlets. First, the old: given the recent economic downturn, at least anecdotally, people are relying on one another again and, as the catchphrase goes, "building stronger communities." There has been a rise in local food co-ops, community gardens, ride shares, buy-local movements, and microcredit projects. ${ }^{46}$ Second, the new: the Internet

45. See Elizabeth Chamblee Burch, Litigating Groups, 61 ALA. L. REV. 1, 9-16 (2009); see also Howard M. Erichson, Beyond the Class Action: Lawyer Loyalty and Client Autonomy in Non-Class Collective Representation, 2003 U. CHI. LEGAL F. 519.

46. See generally Timothy C. Barmann, As Fuel Costs Rise, More People Opt to Share a Ride, ProvidencE J., July 30, 2008, available at NEws BANK, Record No. 20080730-PJ-RIDESHARING-20080730; John Harrington, Project Aims to Place a Garden Plot Within Walking Distance of Every Home, INDEP. REC. (Helena, Mont.), Oct. 11, 2009, available at http:// www.helenair.com/lifestyles/article_44a0fdbc-b61a-11de-885a-001cc4c03286.html; Zlati Meyer, 
has ushered in a community that is both virtual and social. We use text messages, blogs, instant messaging, and e-mail to communicate with one another. Social networking sites like Facebook, Twitter, MySpace, and LinkedIn allow us to stay in touch with people from our former high school, college, and workplace communities. In this sense, social sites reflect our offline, personal interaction. ${ }^{47}$ Sometimes these sites lead people to deepen their friendships by turning acquaintances into real friends. They also allow us to make new friends and join virtual communities, groups, and message boards based on our common interests. Put differently, we can expand our communality by sharing information and joining collective efforts. ${ }^{48}$

Take, for example, the Navy's website for "moms," which includes multiple discussion threads, groups such as "Moms of Officers" and "Moms of Navy Musicians," meeting kits for gathering with other Navy moms in one's hometown, and links to blog posts, photos, and videos. ${ }^{49}$ Its purpose is to give "members a place to discuss issues with others who share common concerns" and "provide an environment of understanding, comfort and belonging to all involved." 50 Similar websites exist for Army wives, Marine Corps wives, and even military children. ${ }^{51}$ Likewise, during the recent economic crisis, homeowners have formed online groups and foundations to help individuals dealing with foreclosure and refinancing. ${ }^{52}$ Some of these communities even develop from shared tragedies and the group litigation that ensues. There are, for instance, websites dedicated to the September 11, 2001 tragedy where people can post their stories and view pictures, videos, and documents, ${ }^{53}$

Rising Gas Prices Fuel Rise in Office Carpooling: Workers Say They Save Big, Enjoy Company, Det. Free Press, May 14, 2007, at A3; Manoj Pant, Op-Ed., Financial Inclusion and Microcredit, ECON. TIMES (India), July 11, 2008, available at http://economictimes.indiatimes.com/opinion /columnists/manoj-pant/Financial-inclusion-and-microcredit/articleshow/3220182.cms; Allie Shah, Stillwater Food Co-Op Has Built Community of Shoppers, STAR TRIB. (Minneapolis, Minn.), Mar. 4, 2008, available at $\mathrm{http}: / / \mathrm{www}$. startribune.com/local/east/16146732.html.

47. See Nicholas A. Christakis \& James H. Fowler, Connected $270-71$ (2009) (“[A]t their core, social-network sites primarily reflect offline interactions.").

48. See id. at 275 (noting that communality has been modified by the Internet).

49. Navy for Moms, http://www.navyformoms.com (last visited Jan. 21, 2010).

50. Navy for Moms, About Us, http://www.navyformoms.com/page/about-us (last visited Jan. 21, 2010)

51. Army Wives, http://www.armywives.com (last visited Jan. 21, 2010); Marine Corps Wives, http://www.marinewives.com (last visited Jan. 21, 2010); Military Kidz, http://www.military kidz.com (last visited Jan. 21, 2010).

52. See, e.g., Avoid Foreclosure, http://groups.yahoo.com/group/Avoid-Foreclosure/ (comprising a group of 854 members dedicated to helping "people get back on their feet" and preventing people from going into foreclosure) (last visited Jan. 21, 2010).

53. The September 11 Digital Archive, http://911digitalarchive.org (last visited Jan. 21, 2010). 
sites for survivors of Hurricanes Katrina and Rita; ${ }^{54}$ and groups for "People against Paxil" and Vioxx Plaintiff Education Groups. ${ }^{55}$ Plaintiffs' attorneys form groups and consortia of their own, such as the "Katrina Litigation Group." ${ }^{, 6}$ In sum, commonalities ranging from having a child in the Navy to mass disasters to tragic drug side effects bring people together globally.

These new communication media take us from local communities to worldwide communities that form from shared experiences, interests, desires, and commitments. They augment our ideas of community. Our fundamental notions about what constitutes a community have remained consistent, but both the media and the moral obligations have evolved. For instance, de Tocqueville's observation that associations shape American societies remains true ${ }^{57}$ but new communication means and methods have made it possible to associate with people beyond our territorial communities.

While some definitions of "community" are static, rooted in territory, and include people living in the same area or interacting populations (towns, neighborhoods, or cities), others capture the relational community as "a group linked by a common policy" and "a body of persons ... having a common history or common social, economic, and political interests." 58 These latter definitions clarify that community is not just about where we live, but about our relationships and affective ties with one another. Community in this sense grows out of social relationships with reciprocity and mutuality. ${ }^{59}$ Thus, key features of the

54. Hurricane Digital Memory Bank, http://hurricanearchive.org (last visited Jan. 21, 2010)

55. People Against Paxil, http://www.facebook.com/group.php?gid=5445754283 (last visited Jan. 21, 2010); Paxil (and Other Antidepressants) Survivors, http://www.facebook.com /group.php?gid=2246304004 (last visited Jan. 21, 2010); Vioxx Plaintiff Education Group, http://groups.yahoo.com/group/MerckSettlement/ (last visited Jan. 21, 2010); see also Byron G. Stier, Resolving the Class Action Crisis: Mass Tort Litigation as Network, 2005 UTAH L. REV. 863, 919-21 (2005).

56. For the opinion disqualifying the Katrina Litigation Group after Dickie Scruggs was arrested, see McIntosh v. State Farm Fire and Cas. Co., No. 1:06CV1080 (S.D. Miss. Apr. 4, 2008) (Op. on Mot. to Disqualify), available at http://www.mssd.uscourts.gov/Insurance\%20Opinions /ch06cv1080orderA0912.pdf.

57. In an often-cited passage, Alexis de Tocqueville states, "Americans of all ages, all conditions, and all dispositions constantly form associations. They have not only commercial and manufacturing companies, in which all take part, but associations of a thousand other kinds ...." 2 AleXIS DE TOCQUeVILle, Democracy IN AMERICA 128 (Henry Reeve trans., Schocken Books 1961) (1835).

58. Merriam-Webster Online Dictionary, Community, http://www.merriam-webster.com/ dictionary/community (last visited Jan. 21, 2010).

59. See Thomas Bender, Community and Social Change in America 122-28 (1978); Gregory S. Alexander, Dilemmas of Group Autonomy: Residential Associations and Community, 75 CORNELL L. REV. 1, 25 (1989). 
definition used here include membership (belongingness with boundaries), influence, integrating and fulfilling needs, and shared emotional connections (history, experiences, and commonalities). ${ }^{60}$

When we compare these expansive definitions of community and the evolving media for forming communities with our stationary legal ideas about cohesion, our current line-drawing scheme appears outdated. Cohesion is static in that courts measure the proxies-requesting uniform relief and having common characteristics that predate the litigation-at a particular point in time. And plaintiffs with procedurally aggregated tort claims are unlikely to exhibit the fundamental attributes of a cohesive local community-social bonds, social activities, and community attachment. $^{61}$ But what if by using new media we could return to the core cohesion seen in small, rural medieval communities without the corresponding geographic restrictions? Put differently, what if we traced actual cohesion regardless of when or where it arose? This amended line-drawing scheme conceives of groups as individuals who exhibit actual affective ties with each other and avoids, as Thomas Bender puts it, the "cynical manipulation of symbols of community." litigants together in nonclass aggregation through multidistrict transfers, claim consolidation, and party joinder can shape relationships, result in plaintiffs forming social bonds, and change the character of those associations into real communities.

Still, my intention is not to propose a radical restructuring of Rule 23 or to suggest that we re-envision the line for true class actions with absent class members. Instead, my concern is with a particular subset of would-be class litigation-mass-tort litigation-where plaintiffs care enough to bring individual suits. Those suits might be aggregated by the claimants, their attorneys, or administratively through multidistrict transfer and consolidation before a single judge. ${ }^{63}$ Although these plaintiffs have retained their own attorney and are present as compared with absent class members, the sheer number of other plaintiffs makes it difficult for attorneys to communicate regularly with their clients and means that clients tend to be poor monitors. Therefore, it is in nonclass aggregation that I am suggesting a change. ${ }^{64}$

60. David W. McMillan \& David M. Chavis, Sense of Community: A Definition and Theory, 14 J. COMM. PSYCHOL. 6, 9 (1986).

61. See generally John Kasarda \& Morris Janowitz, Community Attachment in Mass Society, 39 AM. SOC. REV. 328 (1974) (describing how associational networks affect communities).

62. BENDER, supra note 59, at 144.

63. A.L.I., Principles of the LaW of AgGregate Litigation $\S 1.02$ (Proposed Final Draft 2009).

64. This proposed change should not function retroactively to certify an overarching class 
If the current class action scheme justifies binding interests because they are "similar" (interest representation), then the change that I am suggesting is different in kind. It is based on neither a pure fiction of similar interests nor on pure consent, but is a blend of the two, with heavy weight on both. The basic idea is this: once aggregationprocedural or purposeful-brings people together, giving them the opportunity to interact with one another and discuss their commonalities may lead them to form actual, cohesive groups. Plus, new communication media make it possible for plaintiffs to interact regularly.

Given that "presumed cohesion" justifies binding absent litigants to a class action judgment, if group cohesion in nonclass aggregation is real then there is ample historical and theoretical justification for allowing plaintiffs to limit their ability to pursue their own claims. When litigants form groups and morally obligate themselves to other group members through voluntary promises and assurances, it makes sense to reinforce those obligations legally (or socially) and bind plaintiffs' collective interests regardless of whether their cohesion predated or postdated the decision to sue. ${ }^{65}$ Because I have elaborated on both this theoretical framework for litigating together and methods for implementing the framework elsewhere, I won't rehash either here. ${ }^{66}$ Instead, first, by reconsidering interest representation and consent in the context of political theory, I suggest that redrawing the line around actual groups avoids Redish's argument that group litigation is antidemocratic. Second, continuing to explore the alternative line-drawing scheme in political terms, the final section draws from pluralism and communitarianism to sketch a political framework for promoting group governance. Drawing this new line requires us to afford group autonomy to plaintiffs by allowing them-with the help of a special officer-to self-govern. ${ }^{67}$

where none would exist otherwise

65. Burch, supra note 45 , at 41-47.

66. Burch, supra note 44; Burch, supra note 45.

67. I embrace a weaker form of "group autonomy" because the special officer serves an advisory function. The Stanford Encyclopedia of Philosophy explains the notion of group autonomy as follows:

When people living in some region of the world declare that their group has the right to live autonomously, they are saying that they ought to be allowed to govern themselves. In making this claim, they are, in essence, rejecting the political and legal authority of those not in their group. They are insisting that whatever power these outsiders may have over them, this power is illegitimate; they, and they alone, have the authority to determine and enforce the rules and policies that govern their lives.

Stanford Encyclopedia of Philosophy, Personal Autonomy, http://plato.stanford.edu/entries/personalautonomy/ (last visited Jan. 21, 2010). 


\section{AGgRegating AS A DEMOCRATIC ENTERPRISE}

Thus far, I have contended that group cohesion, regardless of whether it arises before or after the decision to sue, justifies binding collective interests. Of course, this must be clarified a bit. In litigation, this holds true only if - after proper sorting with the help of a third-party neutral (the "special officer") - plaintiffs share means and ends. ${ }^{68}$ Because plaintiffs aggregated procedurally under Rule 20 or transferred through the multidistrict litigation statute may share only a common question of law or fact, their hopes, desires, and intentions toward the litigation may vary wildly. ${ }^{69}$ But in the course of talking things over with one another, plaintiffs might realize that their means and ends mesh. They may begin to think of themselves as being in community with each other. Smaller communities may exist within the larger body of litigation, making the issue of governance between groups similar to that between subgroups and the polity. With this similarity comes all of the attendant problems of intergroup relationships, defining membership, and group autonomy.

To explain how drawing a line around actual groups overcomes the democratic critique in a way that class actions may not, consider again the notions of consent and interest representation. When plaintiffs meet one another, form groups, discuss their litigation ends, and further specify those ends through deliberation, they have an opportunity to participate and be heard in the process. Group deliberation thus serves as a proxy for direct participation in the judicial process, which tends to become less meaningful and practical as the number of plaintiffs increase. $^{70}$ By both consenting - through making promises and assurances to one another to cooperate - and by participating in the decision-making process, individuals retain some autonomy and influence over collective decisions. ${ }^{71}$ Granted, because they are part of a collective and "in it together," they have less autonomy than they might in an individual lawsuit. But in exchange for pure autonomy, they gain

68. This idea and the use of a special officer is expanded greatly in Burch, supra note 44 .

69. See 28 U.S.C. $§ 1407$ (2006) (authorizing multidistrict litigation); FED. R. CIV. P. 20 (authorizing permissive joinder).

70. See Alexandra Lahav, Fundamental Principles for Class Action Governance, 37 IND. L. REV. 65, 79-82 (2003) (stating that "courts understand opt outs as a pure expression of claimant autonomy").

71. See generally Ronald Dworkin, The Concept of Autonomy, in THE INNER CITADEL: EsSAYS ON INDIVIDUAL AUTONOMY 54, 61 (John Christman ed., 1989) (stating that "[t]he full formula for autonomy . . . is authenticity plus procedural independence"); Lon L. Fuller, The Forms and Limits of Adjudication, 92 HARV. L. REV. 353, 364 (1978) (advocating increased participation in adjudication). 
greater bargaining power, sustain a credible threat against the defendant, reduce their transaction costs, and decrease the informational asymmetries that arise between disaggregated plaintiffs and a common defendant. $^{72}$ In short, by making promises and assurances to other plaintiffs and by forming a group, the plaintiff has determined that the benefits of litigating together outweigh the loss of individual decisionmaking autonomy.

It is here that I would like to introduce some threads of political theory for two relatively limited purposes. The first is to make the point that our theoretical options are not limited to either social-welfare maximization or individual autonomy. Instead, strands of communitarianism (or, as some in the field label it, republicanism ${ }^{73}$ ) can explain and harmonize the process in ways that welfare maximization and individual autonomy cannot. My hesitance is that, although those terms help avoid Redish's democratic critique and are convenient shorthand for some of the ideas I find important, they also introduce a flood of other implications that have little to do with the fairly narrow point that I am making here. Nevertheless, I find them useful to rely on with that caveat in place. Second, once we start to think about the plaintiffs in nonclass aggregation as being in a community of sorts, then we can also use democratic thought to explore how much leeway the judicial system should afford them to self-govern.

\section{A. Rethinking the Democratic Difficulty with a Community of Plaintiffs}

Thinking about group litigation in political terms raises similar arguments to those raised in a much larger debate over the individual's role in the democratic state. In political theory, the individual's place in the polity lies at the heart of the debate between liberals and communitarians, or as Charles Taylor urges, between atomists and holists. $^{74}$ Of interest here-without wading in too deeply - is how each school of thought perceives the individual's role in society.

Although both liberals and communitarians value self-determination, liberalism elevates individual autonomy. According to John Rawls and his "justice as fairness" argument, individual autonomy allows people to

72. Burch, supra note 44, at 48-49.

73. See, e.g., Michael J. Sandel, Liberalism and Republicanism: Friends or Foes? A Reply to Richard Dagger, 61 REV. POL. 209, 209 (1999) (stating that Sandel uses the name "republicanism").

74. Charles Taylor, Cross-Purposes: The Liberal-Communitarian Debate, in DEBATES IN CONTEMPORARY POLITICAL Philosophy 195, 195 (Derek Matravers \& Jonathan E. Pike eds., 2003). 
act "from principles that they would acknowledge under conditions that best express their nature as free and equal rational beings." 75 Democratic communitarianism, on the other hand, sees history, social norms, and the process of living in society as crucial elements of individual development. Communitarianism thus does not reduce all moral claims to what an individual would consent to or choose; rather, it contends that individuals can incur responsibilities to one another simply by virtue of being fellow citizens. ${ }^{76}$

Michael Walzer explains the liberal-communitarian debate in terms of less-voluntary forms of association; his words are worth quoting at length:

$[\mathrm{P}]$ eople are born into very important sorts of groups, born with identities, male or female, for example, working class, Catholic or Jewish, black, democrat, and so on. Many of their subsequent associations (like their subsequent careers) merely express these underlying identities, which, again, are not so much chosen as enacted. Liberalism is distinguished less by the freedom to form groups on the basis of these identities than the freedom to leave the groups and sometimes even the identities behind. Association is always at risk in a liberal society. The boundaries of the group are not policed; people come and go, or they just fade into the distance without ever quite acknowledging that they have left. That is why liberalism is plagued by free-rider problems - by people who continue to enjoy the benefits of membership and identity while no longer participating in the activities that produce those benefits. ${ }^{77}$

Even though he writes in a political context, Walzer's observations about free riders and unchosen associations apply with equal force in the procedural aggregation context. No rational person chooses to be injured by a drug or product, but once it happens to her and to many others with aggregated claims, they are all in it together. Under the current centralplanning model, plaintiffs have few, if any, options to exit the

75. John RaWls, A Theory of Justice 515 (Harvard Univ. Press 1971). No universal definition of "autonomy" exists, but a detailed treatment of the subject is beyond this Article's scope.

76. See Michael J. Sandel, Justice 223-25 (2009); Charles Taylor, Atomism, in 2 Philosophy AND THE Human SCIENCES: PhilosophicAl PAPERs 187, 204 (1985); Michael Walzer, The Communitarian Critique of Liberalism, 18 POL. THEORY 6, 15-16 (1990).

77. Walzer, supra note 76 (citation omitted); see also SANDEL, supra note 76, at 220 ("If we understand ourselves as free and independent selves, unbound by moral ties we haven't chosen, we can't make sense of a range of moral and political obligations that we commonly recognize, even prize." Among such obligations, include those "of solidarity and loyalty, historic memory and religious faith - moral claims that arise from the communities and traditions that shape our identity.”); CHARLES TAYLOR, SOURCES OF THE SELF 36 (1989). 
aggregation, though they may remain disengaged from one another. In class action litigation, on the other hand, entrepreneurial plaintiffs' attorneys overcome collective-action problems by initiating litigation on others' behalf. Of course, it is the entrepreneurial effort of one on "behalf" of many that prompts Redish's democratic critique, that this effort undermines the individual decision to sue and to direct the course of that lawsuit. ${ }^{78}$ But, at least technically, in nonclass aggregation no one person or small group of attorneys has nearly exclusive control over others' right to sue in tort. This means, however, that the temptation to free-ride is back, as is a new temptation to hold out by strategically withholding consent in hopes of a higher payout when a settlement demands nearly unanimous consent. Thus, the question has shifted to what role the plaintiffs should play in this nonclass aggregation systema system in which they tend to have little control because of the sheer numbers of nominally related plaintiffs, the difficulty of communicating with multiple clients, and the inherent agency problems that arise when one agent represents numerous principals with (sometimes) divergent interests.

Drawing a line around actual, cohesive groups changes the calculus in some interesting ways. First, in order to be in a group, the plaintiffs must have implicitly consented. ${ }^{79}$ As I have explored in greater detail elsewhere, once plaintiffs begin communicating with one another about their intentions concerning the litigation, they may reach broad agreement about particular ends and make promises and assurances to one another to act in ways that further those joint ends. ${ }^{80}$ Those promises and assurances form the social glue holding the group together; they are moral obligations made voluntarily. Plus, because individuals have exercised their free will to associate with other litigants, this alternative line preserves the fundamental tenets of self-determination and consent in liberal theory. ${ }^{81}$ One might claim that this attribute makes these groups contractarian. For instance, as Michael Sandel explains the liberal account of obligation: "Whether we must concern ourselves with the good of other people depends on whether, and with whom, we have agreed to do so." 82 But to claim an exclusively liberal and atomistic view ignores the complex psychological and social dynamics of groups,

78. Redish, supra note 38 .

79. Burch, supra note 45 , at $42-43$.

80. Id. at $45-46$.

81. See RAWLS, supra note 75 , at 108-17 (explaining that obligations can arise through voluntary acts, such as promises and agreements, and natural duties).

82. SANDEL, supra note 76 , at 224. 
the moral component of promising, and the transformative nature of social relationships - if not in a metaphysical sense, in a pragmatic, obligation sense.

Picking up on this thread of morality and obligation brings me to the second way in which redrawing the line around actual, cohesive groups changes the litigation calculus. Group membership means that the individuals contained within it have certain obligations to one another. Granted, to say that someone is a group member says nothing about the nature or content of those obligations. But suppose that there is a proportional and reciprocal obligation (made, once again, through voluntarily issued promises, assurances, or even tacit agreements) to cooperate with one another. ${ }^{83}$ The liberal account of obligations as consisting of voluntary promises would capture this aspect, but it fails to account for obligations of solidarity or membership. ${ }^{84}$ Put differently, as soon as two people disagree over what it is to cooperate and thus what they have agreed to do, their obligations to one another may end. But if they have incurred additional obligations of solidarity or membership by virtue of being in community with one another, then they're not off the hook so easily (at least morally). ${ }^{85}$

It is here that communitarianism plays a role. Plaintiffs who have decided to work together, who have turned themselves into a "plural subject," define the relevant community. ${ }^{86}$ A "plural subject" might mean many things, but I use the term in a basic sense: when a set of "I's" becomes a single, plural subject-a "we." ${ }^{87}$ When plaintiffs decide to harness their fates together, to "pursue our goal" or to "win our litigation," they are in it together. (I take it as a given here that a special officer has helped sort plaintiffs into groups with like injuries and claims so that their individual interests align with the group's collective interest.) ${ }^{88}$ The power of self-determination now rests with the collective in a way that furthers communal interests and values, that carries out, in other words, their obligations of solidarity. What's different, however, is

83. Although communitarians distinguish between voluntary associations and communities, the distinctions are not categorical and the characteristics tend to overlap. The main question is whether social relationships are based on reciprocal empathy, not just a means for attaining an individual instrumental end. Alexander, supra note 59, at 26.

84. SANDEL, supra note 76 , at 225.

85. To be sure, moral obligations can be quite different from legal obligations. This obligation of solidarity does not readily translate into a legal obligation. See Burch, supra note 44, at 18-20.

86. MARgaret Gilbert, Sociality AND ReSPONSIBILITy 3 (2000); see also Burch, supra note 45, at 23-26. I borrow this term from Margaret Gilbert, but do not use it in exactly the same way that she does.

87. Burch, supra note 45, at 23-26.

88. For more about this sorting process, see Burch, supra note 44. 
that because we are talking principally about a voluntary exercise of the will, through commitments and promises to other plaintiffs, we need not completely disregard the norms of individual liberalism nor enter the morass of hypothetical consent and social-contract theory. ${ }^{89}$ The "catch" from the liberal perspective is that once litigants make reciprocal promises and assurances to one another to cooperate, they are not free to leave the group if doing so would violate those promises or their obligations of solidarity. Conversely, the disjunction with Sandel's version of communitarianism is that these obligations of solidarity or membership arise only after plaintiffs have defined the membership through their voluntary association and can be captured, at least initially, by an ethic of consent. ${ }^{90}$

Consider an analogy to labor unions. The 1930s Wagner Act made it possible for American workers to transform their unified interests and solidarity into a formal bargaining unit when a majority of workers favored the arrangement. It thus overcame their collective-action problem and, in some ways, the principal-agent problem (though it surely created others) by allowing members to vote. Similarly, by encouraging plaintiffs to communicate and associate with one another, several things happen. First, after grouping with others who want similar ends and have similar injuries, their interests are more cohesive. According to current class action theory, this justifies binding their interests collectively. Second, they are able-like unionized employees-to better negotiate with their attorneys, monitor the litigation, and participate in the process. ${ }^{91}$ Third, unlike unions, the process of voluntarily associating with one another does not per se involve those who would prefer to be left out of the arrangement altogether. It thus preserves a liberal sense of autonomy: one chooses whether to join the group and how much to participate.

In sum, once we disaggregate the notion of group from the narrow inquiry of whether cohesion predates the litigation, we can avoid some of the problems caused by treating heterogeneous individuals as if their interests are unitary. Binding interests that become unitary post litigation

89. See Ronald Dworkin, The Original Position, 40 U. CHI. L. REV. 500, 519-33 (1973).

90. SANDEL, supra note 76, at 241 ("We've been trying to figure out whether all our duties and obligations can be traced to an act of will or choice." Sandel does not believe they can and argues that "obligations of solidarity or membership may claim us for reasons unrelated to a choicereasons bound up with the narratives by which we interpret our lives and the communities we inhabit."). Again, my point here is to use these philosophies in a narrow way, in the context of nonclass aggregation, and not to make broader statements about their salience.

91. This might include a voting arrangement if the litigants have agreed to an intraclaimant governance arrangement. Burch, supra note 44. 
eliminates the concern over representing absent group members. It allows present plaintiffs to specify their interests and then pursue homogeneous ends together. Litigating collective interests collectively allows plaintiffs to present a unified, credible threat against the defendant, to bargain and deliberate about what those collective interests are and how they should go about fulfilling them, and to participate in the process of pursuing their substantive rights. Put simply, diverse subgroups with heavy plaintiff participation and deliberation are more like an actual community (at least with regard to the litigation issues) than a class action with absent class members or even classes with a preexisting trait that has little to do with actual cohesion.

\section{B. Community Self-Governance}

Thus far, we have covered the criteria for subgroup membership: sharing like intentions toward the defendant; having similar claims and injuries; and, most importantly, making promises and assurances to cooperate with one another in achieving the group's joint ends. The event or events giving rise to the litigation-from taking and experiencing the effects of the same drug (Vioxx, Zyprexa); to sharing circumstances and histories (Vietnam in the Agent Orange Litigation, being in the same nightclub fire together, or experiencing the same hurricane or flood); to having the same product malfunction in ways that change their lives (Bridgestone/Firestone Tire Litigation) - bring people with shared emotional connections together. ${ }^{92}$ As I've hinted, in largescale litigation it is highly unlikely that all plaintiffs will agree on their litigation ends, that they will have the same or even highly similar injuries, that they have uniformly strong claims, or that the same laws will apply. Consequently, while further sorting like interests with other like interests, subgroups will form.

Although this situation raises a constellation of questions about how these subgroups interact with one another and how they could or should reach decisions, my focus here is on a narrower issue. ${ }^{93}$ If courts recognize this alternative line-drawing scheme and foster group formation after both the decision to sue and procedural aggregation, what

92. In re Bridgestone/Firestone, Inc. Tires Prod. Liab. Litig., 288 F.3d 1012, 1016-17 (7th Cir. 2002); In re Vioxx Prod. Liab. Litig., 574 F. Supp. 2d 606, 611-12 (E.D. La. 2008); In re Zyprexa Prod. Liab. Litig., 433 F. Supp. 2d 268, 271 (E.D.N.Y. 2006); Gray v. Derderian, 400 F. Supp. 2d 415, 419-20 (D.R.I. 2005); Louisiana v. All Prop. \& Cas. Ins. Carriers, 937 So. 2d 313, 316-18 (La. 2006); Peter H. Schuck, Agent ORANGe ON TRIAL 25-26 (1986).

93. I've explored many of these other issues in Burch, supra note 45. 
degree of autonomy ought the judicial system afford these litigation groups?

One might think about subgroup and superordinate group autonomy and why autonomy is valuable in terms of either pluralist or communitarian theories. Although there is a great deal of tension between the two perspectives, both have something to offer modern litigation groups. By pluralists, I mean public-choice theorists who focus on the role of and interplay between societal groups, which they view as the organizational form for allowing a collection of individuals to further their own interest. Some pluralists might explain the need for group autonomy based on the freedom of association: so long as individuals have openly agreed to associate, they should be able to establish the terms and conditions of their relationships and should be free to leave the group whenever they like. ${ }^{94}$ Other pluralists might contend that having diverse subgroups with multiple perspectives on remedies and forceful advocacy within litigation helps counter agency problems caused by a strong plaintiffs'-attorney steering committee and weak client monitoring. ${ }^{95}$ Empowering groups ensures that their members have access to the decision-making process and better insulates them from attorney neglect. ${ }^{96}$

Pluralist thought takes up the familiar idea pushed by liberalsindividual autonomy - and imports it into the group context by viewing groups as an instrumental means for pursuing individual interests. ${ }^{97}$ The group is an association of individuals who each use the group to promote their own welfare. ${ }^{98}$ Accordingly, the prescriptive lesson from pluralist thought is that the judicial system should foster and enable group formation, help sort plaintiffs into homogeneous subgroups, and enforce the rules created through group governance because these rules reflect the group's values and objectives. Embracing pluralist ideas by maintaining subgroups in aggregate litigation introduces dissent, which

94. See generally RoBert NOzICK, ANARCHY, StATE, AND UtOPIA 299-306 (1974).

95. See W. Russell Neuman, The Paradox of Mass Politics: Knowledge and Opinion IN THE AMERICAN ELECTORATE 126-27 (1986); Rhode, supra note 17, at 1223-24. Robert Dahl has written several books providing a general account of pluralism in the political process. See generally Robert A. Dahl, Dilemmas of Pluralist Democracy: Autonomy vs. Control (1982); Robert A. Dahl, Pluralist Democracy in the United States: Conflict AND CONSENT 22-24 (1967).

96. See Robert A. Dahl, A Preface to Democratic Theory 104-05 (1956); Michael WALZER, OBLIGATIONS: ESSAYS ON DISOBEDIENCE, WAR, AND CITIZENSHIP 224 (1970).

97. See Alexander, supra note 59, at 2.

98. See id. at 20 . 
often results in better-developed arguments, new ideas, forceful advocacy, and - ultimately - increased legitimacy. ${ }^{99}$

Like pluralists, communitarians view social groups and the need for group autonomy as promoting social good. ${ }^{100}$ But communitarians define "social good," in part, as the intrinsically invaluable process of group participation that leads one to define and fulfill her identity. ${ }^{101}$ Communitarianism recognizes that with membership comes obligationeven when people consent to membership and even when individual promises and assurances glue the group together. ${ }^{102}$ By designing an arrangement that reflects members' commitments to one another and captures community preferences for decision making, litigants can legitimately curtail exit mechanisms. ${ }^{103}$ This means, however, that litigant communities must have some autonomy to self-govern and that the judge should both enforce those arrangements and-by using a special officer to avoid bias and the appearance of bias - help coordinate subgroup and superordinate group relationships. ${ }^{104}$

When plaintiff communities form from plaintiffs' affective ties with each other, those communities mix contractarian and communitarian dimensions. Although plaintiffs may voluntarily enter the group because of a utilitarian cost-benefit analysis or for purely instrumental reasons, once they are group members and have tied their collective litigation fates together, their interactions tend to change their relationships. Social psychologists and behavioral law-and-economics theorists characterize this change in terms of developing other-regarding preferences. ${ }^{105}$ It is

99. See NeUMAN, supra note 95, at 126-27.

100. Alexander, supra note 59 , at 30.

101. See id. at 30-32 (describing the good as "fulfillment of the self achieved through ... community").

102. See id. at 26-28, 32 .

103. For other discussion on this topic of exit, see Burch, supra note 45.

104. See generally A.L.I., supra note 63, § 3.17, § 1.05(c) (suggesting that judges should "enforce parties' agreements regarding the conduct of litigation" and that litigants might enter into an agreement governing their relationship and voting procedures).

105. See generally Robert Axelrod \& William D. Hamilton, The Evolution of Cooperation, 211 SCI. 1390 (1981); Kelly S. Bouras \& S.S. Komorita, Group Discussion and Cooperation in Social Dilemmas, 22 Personality \& Soc. Psychol. Bull. 1144, 1145 (1996); Robert Boyd \& Peter J. Richerson, Cultural Transmission and the Evolution of Cooperative Behavior, 10 HUM. ECOLOGY 325 (1982); Nancy R. Buchan et al., Let's Get Personal: An International Examination of the Influence of Communication, Culture and Social Distance on Other Regarding Preferences, $60 \mathrm{~J}$. ECON. Behav. \& ORg. 373, 373-75 (2006); Joseph Henrich, Cultural Group Selection, Coevolutionary Processes and Large-Scale Cooperation, 53 J. ECON. BEHAV. \& ORG. 3 (2004); Norbert L. Kerr \& Cynthia M. Kaufman-Gilliland, Communication, Commitment, and Cooperation in Social Dilemmas, 66 J. Personality \& Soc. Psychol. 513, 526-27 (1994); Mark Van Vugt \& Claire M. Hart, Social Identity as Social Glue: The Origins of Group Loyalty, 86 J. PERSONALITY \& SOC. PSYCHOL. 585, 586 (2004). 
here that pluralist or liberal thought fails to satisfactorily explain the layers within social relationships and where a thicker conception of moral obligation is needed. Otherwise, this account cannot reconcile theory with reality. I thus find the concept of a plural subject a useful alternative. ${ }^{106}$ The theory is that you and I and many others might want to do something together, to be jointly committed to attaining a particular end and to specifying our day-to-day plans for fulfilling that end without becoming an "entity" in the ontological sense, but without acting as completely self-regarding individuals either.

Maintaining subgroups comprised of plural subjects who have reached consensus about their litigation ends, who experienced similar injuries, and who are thus more than nominally related protects individuality without forgoing community. It also avoids a problem with the entity theory, that once the entity exists, it can suppress individual objections and cram down subsequent tensions between the principals (the litigants) as well as between the principals and the agents. ${ }^{107}$ Fostering subgroups of plural subjects requires the aid of a special officer who provides information and helps protect voice opportunities within subgroups as well as the diversity of groups themselves. Put differently, the special officer maintains group pluralism and each group designs its own governance. ${ }^{108}$

Maintaining a pluralistic subgroup structure does, however, create tension between unity and cohesion on one hand and diversity on the other. There is a risk that strongly autonomous groups will alienate themselves from other plaintiffs. When a settlement offer demands nearly unanimous consent, the larger community must decide what to do and how to go about doing it. If the overarching community lacks consensus, then it can resolve the dilemma by arguing, bargaining, voting, or any combination thereof. ${ }^{109}$ Plaintiffs might aggregate

106. See supra notes $87-88$ and accompanying text.

107. See Issacharoff, supra note 34 , at 374 .

108. I have suggested in Litigating Together: Social, Moral, and Legal Obligations that plaintiffs might design a representative structure, where some subgroup members would represent the interests of the subgroup on a steering committee. Burch, supra note 44, at 42-45. Most communitarians would say that political participation must be unmediated in this way and that members' views should be filtered through an intermediary. See, e.g., Benjamin B. BARBER, Strong DemOCRACY: PARTiCiPATORY POlitics FOR A NeW Age 261 (1984); Gerald E. Frug, The City as a Legal Concept, 93 HARV. L. REV. 1057, 1067-73 (1980). The reality, however, is that some litigants may not want the litigation to become their lives; they have other demands on their time that they must prioritize.

109. Jon Elster, Introduction to DeliBerative Democracy 1, 5 (Jon Elster ed., 1998). Will

Kymlicka describes a similar dilemma over governance in countries that are both multinational and polyethnic:

Self-government rights, however, do pose a threat to social unity. The sense of being a distinct nation within a larger country is potentially destabilizing. On the other hand, the 
members' preferences (voting), transform members' preferences through deliberation, or misrepresent members' preferences by acting strategically. ${ }^{110}$

Deliberating and voting are particularly relevant to the subgroup and superordinate community structure. A system with a mix of deliberating and voting would first allow plaintiffs to deliberate over the merits and fairness of the settlement offer in an attempt to transform preferences. After hearing those arguments (provided that plaintiffs have agreed to a collective decision-making arrangement) ${ }^{111}$ plaintiffs would vote. That vote would bind the entire community. Both deliberating and bargaining may play a role when plaintiffs, with their attorneys' advice, first decide on and consent to a collective decision-making arrangement. For example, plaintiffs with more severe injuries and fewer causation problems might legitimately push for a weighted voting structure that would lessen the potential for a majority of claimants with weaker claims to dilute the voting pool. ${ }^{112}$ All plaintiffs would have equality of access to the deliberation process, but not all plaintiffs would have equal voting strength. ${ }^{113}$

Notice the parallel between genuine dialogue within the plaintiff community about decision making and the idea of a deliberative democracy where "democracy revolves around the transformation rather than simply the aggregation of preferences." deliberation by those who are subject to collective decisions enhances democratic legitimacy, it also enhances judicial legitimacy by supplying a fundamental component of procedural justice - the right to participate and be heard. ${ }^{115}$ To create and maintain community, deliberation is not

denial of self-government rights is also destabilizing, since it encourages resentment and even secession. Concerns about social unity will arise however we respond to selfgovernment claims.

Will Kymlicka, Multicultural Citizenship: A Liberal TheOry of Minority Rights 192 (1995).

110. Elster, supra note 109 , at 6.

111. See Burch, supra note 44 , at $42-45$.

112. Burch, supra note 44 , at $62-64$.

113. Plaintiffs might reach a similar result without having to value one another's claims by requiring a supermajority of roughly eighty percent or more to accept a settlement offer.

114. Elster, supra note 109 , at 1.

115. John S. DryzeK, Deliberative Democracy And Beyond: Liberals, Critics, CONTESTATIONS 1-2 (2000). As to procedural justice, see TOM R. Tyler, Why PEOPLE OBEy THE LAW 133 (1990) (discussing literature evaluating the effects of increased litigant participation); see also E. Allan Lind et Al., The Perception of Justice: Tort Litigants' Views of Trial, COURT-ANNEXED ARBITRATION AND Judicial SETTLEMENT CONFERENCES 61 (1989) (discussing litigants' perceived control of the litigation process); E. ALLAN LIND \& TOM R. TYLER, THE SOCIAL PSYCHOLOGY OF PROCEDURAL JUSTICE 96-97 (1988) (discussing different theories for control over 
limited to arguments or rhetoric, but includes storytelling, personal testimony, humor, reasons, explanations, and even gossip. ${ }^{116}$ Communicating in this way allows plaintiffs to influence and, if they so desire, to vote and be bound by collective outcomes.

Thus, if we define democracy as the extent to which the preferences of the governed influence collective outcomes, then reconceiving the line-drawing scheme can preserve and further core democratic values. ${ }^{117}$ Granted, this concept of democracy is abstract, but it must be. Opinions about democracy vary greatly-from communitarian to liberal-and truly democratic decisions must reflect the collective preferences of the governed.

During deliberation, certain norms of propositional truth, rightness, and truthfulness tend to steer and anchor debates, thereby compelling even self-interested members to phrase their arguments in terms of what is best for the group. ${ }^{118}$ As I have argued elsewhere, group membership and deliberation may have a transformative effect that leads to otherregarding preferences and thereby diminishes the potential for actors to behave purely as homo economicus. ${ }^{119}$ But to reach this point, we must be willing to recognize that we communicate with one another in new ways, that communities are not limited to workplaces or neighborhoods, and that true communities and regard for others arise out of our affective ties - regardless of whether those ties exist before or after the decision to sue.

\section{CONCLUSION}

This Article reconsiders the line-drawing scheme for nonclass aggregation and hews historic rationales for group treatment to fit a new kind of group. Put simply, once the judicial system determines that class

process and procedural fairness); Linda Musante et al., The Effects of Control on Perceived Fairness of Procedures and Outcomes, 19 J. EXPERIMENTAL SOC. PSYCHOL. 223, 237-38 (1983) (describing a study where "[r]egardless of role in a dispute, the opportunity to exercise control through the selection of a decision rule (no matter what the rule) resulted in enhanced evaluations of all aspects of the trial experience"); Patrick Woolley, Rethinking the Adequacy of Adequate Representation, 75 TEX. L. REV. 571, 602-04 (1997) (discussing the extent to which a class member has a right to participate in class litigation).

116. See DRYZEK, supra note 115, at 1 (applying a "tolerant position" on what constitutes authentic deliberation). For other variations on what counts as deliberation, see Elster, supra note 109 , at 8-9.

117. DRYZEK, supra note 115 , at 2 .

118. See generally 2 JÜRgEN HABERMAS, THE THEORY OF COMMUNICATIVE ACTION (Thomas McCarthy trans., 1987).

119. Burch, supra note 44, at 28-32; Burch, supra note 45, at 47-53. 
action treatment is inappropriate, but litigants meet the loose requirements for party and claim joinder under Federal Rules of Civil Procedure 20 and 42, then judges should foster communication and dialogue among the plaintiffs. Plaintiffs who communicate with one another-regardless of whether they are in the same geographic location-often form social bonds, as do, for example, Navy moms, Army wives, and hurricane victims. Somewhat like medieval communities, they actually share affective ties and their relationships evolve organically. This alternative scheme thus avoids presupposing unity where none actually exists. By relying on plaintiffs' voluntary promises and assurances to one another rather than on preexisting external conditions such as the same skin color, employer, gender, or injuries, this amended line need not bind litigants based on fictitious notions of representation.

This line allows litigants to embrace more of a democratic ideal; the communication process helps plaintiffs identify and specify their litigation ends, sort themselves into groups with like-minded individuals, and, ultimately, use this process to make key decisions about litigation strategy and when and whether to settle. No longer can one attorney or one group of attorneys make autocratic decisions on the group's behalf. Correspondingly, the judicial system's role is to afford the group some autonomy to self-govern, subject to the special officer's aid and oversight. That governance regime is ultimately constrained by due process, the mechanisms by which due process makes its way into each state's rules of professional conduct, and adequate representation. ${ }^{120}$ Yet, it allows plaintiffs to cooperate with one another, to bind themselves to the group process, and to limit or eliminate their ability to exit that group. By questioning the assumption that groups must predate the decision to sue, particularly in mass-tort litigation, we can avoid tenuous justifications about interest representation and hypothetical consent and make process more democratic.

120. See Martin v. Wilks, 490 U.S. 755, 756 (1989) (stating that "the linchpin of the 'impermissible collateral attack' doctrine - the attribution of preclusive effect to a failure to intervene-is inconsistent with" Federal Rules of Civil Procedure), superseded by statute, Civil Rights Act of 1991, Pub. L. No. 102-166, 105 Stat. 1074, as recognized in Stender v. Lucky Stores, Inc., 780 F. Supp. 1302 (1992); Phillips Petroleum Co. v. Shutts, 472 U.S. 797, 798 (1985) (stating that "the procedure followed by Kansas, where a fully descriptive notice is sent first-class mail to each class member, with an explanation of the right to 'opt-out,' satisfies due process"); Hansberry v. Lee, 311 U.S. 32, 41 (1940) (stating that "the judgment in a 'class' or 'representative' suit, to which some members of the class are parties, may bind members of the class or those represented who were not made parties to it"); see also Woolley, supra note 115, at 602-03 (discussing the implications of Shutts). 